\title{
DOES AN ATTRACTIVE PENSION PRODUCT DESIGN SELL BY ITSELF? THE EXPERIENCE OF THE CZECH REPUBLIC. ${ }^{1}$
}

\author{
Jiř́i Šindelář, Michal Erben*
}

\begin{abstract}
This paper deals with the experience of third pillar reform in the Czech Republic, executed in 2013. The core of our study is formed by a comparative analysis of newly introduced supplementary pension savings and its substitute products (investment funds, life insurance) from two main aspects: product features and distribution features. The outcomes are supported by empirical sales and population penetration of the surveyed products. The results indicate that even a pension product with a very attractive product design, such as supplementary pension savings, will be hampered by its substitutes as long as its distribution features are unattractive. This is an important lesson, particularly for the discussed European solution, the pan-European portable pension product (PEPP).
\end{abstract}

Keywords: pension reform, third pillar, investment fund, life insurance, distribution JEL Classification: H55, J32, G22, G28

\section{Introduction}

On 1st January 2013, a comprehensive pension reform was launched in the Czech Republic. As such, it was based on four main components: (i) an increase in the retirement age based on the increasing survival age, (ii) establishment of a second pillar opt-out retirement savings product, (iii) transformation and closure of the old third pillar supplementary pension insurance system and (iv) the establishment of a new third pillar solution under the new supplementary pension savings product (Andel, 2014; Batty and Hailichova, 2012). According to the expert committee associated with the government at that time, the goals of the reform were fourfold (PES, 2010): greater diversification, fiscal sustainability, fairer distribution of the intergenerational burden over time and a certain increase in equivalence. As such, the reform followed similar changes undertaken in most neighbouring Central-Eastern European countries (Schneider, 2011). However, the core of the reform consisting of a new second pillar solution gradually began to attract criticism from political opposition and spurred critical discussion among academia (Vostatek, 2012; Loužek, 2014; Krebs, 2013; Janíčko and Tsharakyan, 2013), prompting its deposition by the new government in 2016. On the contrary, substantial changes implemented in the third pillar were mostly not reflected in the public and scholarly discourse, which is rather surprising, given the system's massive prevalence among the Czech population. ${ }^{2}$

Almost five years after the Czech experience, the European Commission finds itself in the middle of a discussion about the Pan-European Pension Product (PEPP), a portable

1 This paper was prepared with the contribution of institutional support for the long-term conceptual development of the University of Finance and Administration research organisation.

2 Over 5.1 million unique contracts were registered as of $1 / 2013$ for a total population of 10.5 million inhabitants (MF, 2018).

* University of Finance and Administration, Prague (sindelar@mail.vsfs.cz). 
third pillar solution that bears surprising similarities with the Czech third pillar changes introduced back in 2013. As with the supplementary pension savings, the PEPP creators visibly seek to build a product that will encompass the following: 'The PEPP could be provided online, including advice, and would not require a network of branches, allowing easier market access...standardising the key features should also reduce providers' costs and help them pool contributions from different national markets...regarding investment policy, consumers will have a choice between a safe default investment option and alternative options with different risk-return profiles' (European Commission, 2017, p. 3). Analogical features were implemented in the Czech solution, as will be shown later. Hence, important lessons learned can be drawn from the subsequent Czech experience in relation to the new European solutions in order to avoid mistakes that were, arguably, responsible for the less than successful archetypal pension reform.

With respect to the above, this paper seeks to draw experience from the Czech third pillar pension reform, in particular, to evaluate the effect of its regulatory regime and product features on market sales and population penetration. In order to achieve this goal, the analytical part of the paper is divided into two main sections. First, a comparative analysis of supplementary pension savings and competitive investment products is undertaken. The outcomes are then projected on the sales developments, and the potential effects of key regulatory decisions are discussed. Finally, the lessons learned are summarised in relation to analogous third pillar projects, particularly to the crucial PEPP European initiative.

\section{Method and Data}

The empirical part of this paper is based on a comparative analysis of supplementary pension savings (SPS) and substitute products. These include (old) supplementary pension insurance, which still holds a substantial market share, regular investment funds and unit-linked life insurance. As most of the SPS sales production in the 2013-2018 period was aimed towards conservative strategy funds, ${ }^{3}$ conservative strategy substitutes were used as the basis of our analysis. The analysis is divided into two parts: (i) product features, summarising key product architectural points, and (ii) distribution features, mapping key distribution attributes. A simple time series projection was then employed to assess the potential effect of supplementary pension savings design features on final market sales. In undertaking the analysis, secondary market data published by the Ministry of Finance, Czech Republic (MF), the Czech national bank (CNB) and the Czech Capital Market Association (AKAT) was utilised. Open data from individual product providers, acquired by the Association of Pension Funds of the Czech Republic (APS) was also incorporated, specifically into the comparative part. ${ }^{4}$

\section{Results}

\subsection{Comparative Analysis - Product Features}

The first part of the analysis compares the main product design features of the four systems surveyed. We take the front-end perspective that is related to the client's point of view

3 During the first year after the reform (2013), over $83 \%$ of contributors' assets were placed in conservative strategies (APS, 2017).

4 There were a total of 11 pension companies as of $1 / 2013$. 
and since the paper deals with supplementary pension savings, sales and marketing, the institutional aspects are not included. Finally, there is a comparison of the state of the offerings as of $1 / 2013$, when the Czech pension was launched.

Clearly, while most of the product features were for pension products strictly defined by law, they were designed in a very pro-client manner. The fees for pension funds are notably lower than their investment or insurance counterparts with no up-fronts, ${ }^{5}$ which is an advantage that is further amplified by generous direct state subsidies and tax benefits. The main potential downside is represented by a restricted preliminary surrender option, in line with retirement-data alignment. This is, however, compensated for by the frequent up-front charges in investment funds and particularly life insurance, which also makes preliminary surrender disadvantageous. This is even more so when occasionally an explicit exit fee is present. It should also be noted that while the above is related to the conservative (bond) investment strategy option, similar relations are also true for other typical strategies including mixed, life-cycle and dynamic (stocks). This point represents another notable difference. While pension savings programmes are, in theory, not too restricted in their strategies, aside from the obligatory conservative funds, in practice they offer much narrower options than the vast opportunities investment funds can provide (typically single conservative, dynamic and life-cycle, with a high portfolio similarity). Nevertheless, both the supplementary pension savings and the former supplementary pension insurance still outstrip their competitors, representing cheaper and more subsidised, albeit more homogeneous, savings (investment) solutions.

The perspective can now be switched from the client to the sales agent (distributor), which typically represents the other party in the sales process. ${ }^{6}$ In the following table, the most important cost/benefit traits from the distributor's point of view are outlined, completing the marketing circle of a typical distribution channel.

The landscape at this point is even more heterogeneous. Clearly, the pension savings regulation was projected in a way that offers, in theory, a high level of consumer protection - commissions capped, strict entrance exams, and the highest code-of-conduct level. However, this creates a serious imbalance and arbitrage from the sales perspective. Consider a simple example: if a sales-agent is able to close a single average contract per week, arguably a typical number, the investment fund with up-front costs and unit-linked insurance will provide them with more than ten times higher earnings in the case of a fund and even more than twenty times higher revenue with life insurance. This is coupled with a mostly less strict regulatory regime, which makes the distribution process less costly and demanding from the compliance perspective. Clearly, this imbalance seriously affected the dominant agent-based distribution channel, as will be shown further. This is combined with an indirect regulatory cap on promotion costs (through regulated fees) that inhibit demand-pull possibilities. Therefore, the sales and marketing options of the new third pillar solutions are seriously affected.

5 Even lower values can be found on some developed markets; however, for example, in the U.S. the average TER of comparable pension products reached only $0.78 \%$ (Lhotská, 2014).

6 In the 2011-2012 period, on average around 30-40\% of new contracts were sold through independent sales agents - financial advisers and intermediaries (USF, 2018). The rest of the production was sold directly through the bank branches and captive networks. 


\begin{tabular}{|c|c|c|c|c|c|}
\hline & $\begin{array}{l}\text { Supple- } \\
\text { mentary } \\
\text { pension } \\
\text { savings } \\
(\mathrm{SPS})^{A}\end{array}$ & $\begin{array}{l}\text { Supple- } \\
\text { mentary } \\
\text { pension } \\
\text { insurance } \\
(\mathrm{SPI})^{\mathrm{A}}\end{array}$ & $\begin{array}{l}\text { Investment } \\
\text { fund } \\
\text { (IF) with } \\
\text { up-front } \\
\text { commission }{ }^{A}\end{array}$ & $\begin{array}{l}\text { Investment } \\
\text { fund } \\
\text { (IF) without } \\
\text { up-front } \\
\text { commission }{ }^{A}\end{array}$ & $\begin{array}{l}\text { Unit-linked } \\
\text { life } \\
\text { insurance } \\
\text { (ULI) }^{A}\end{array}$ \\
\hline $\begin{array}{l}\text { Available } \\
\text { strategies }\end{array}$ & $\begin{array}{c}\text { Conservative } \\
\text { (public and } \\
\text { investment } \\
\text { grade bonds) } \\
\text { (set forth by } \\
\text { law }^{\mathrm{B}} \text { ). } \\
\text { Other offers } \\
\text { ranging from } \\
\text { conser- } \\
\text { vative to } \\
\text { dynamic } \\
\text { strategies. }\end{array}$ & $\begin{array}{c}\text { Conservative } \\
\text { (public and } \\
\text { investment } \\
\text { grade bonds), } \\
\text { with no loss } \\
\text { guarantee } \\
\text { (set forth by } \\
\text { law }^{\mathrm{B}} \text { ). }\end{array}$ & $\begin{array}{c}\text { No limitations, } \\
\text { offers } \\
\text { ranging from } \\
\text { conservative } \\
\text { to dynamic } \\
\text { strategies. }\end{array}$ & $\begin{array}{l}\text { No limitations, } \\
\text { offers } \\
\text { ranging from } \\
\text { conservative } \\
\text { to dynamic } \\
\text { strategies. }\end{array}$ & $\begin{array}{c}\text { No limitations, } \\
\text { offers } \\
\text { ranging from } \\
\text { conservative } \\
\text { to dynamic } \\
\text { strategies. }\end{array}$ \\
\hline $\begin{array}{l}\text { State } \\
\text { subsidy }\end{array}$ & $\begin{array}{c}\text { State } \\
\text { contributes } \\
\text { max. } 690 \mathrm{CZK} \\
\text { per } 1000 \mathrm{CZK} \\
\text { of the client's } \\
\text { payment. }\end{array}$ & $\begin{array}{c}\text { State } \\
\text { contributes } \\
\text { max. } 690 \mathrm{CZK} \\
\text { per } 1000 \mathrm{CZK} \\
\text { of the client's } \\
\text { payment. }\end{array}$ & None & None & None \\
\hline Tax benefits & $\begin{array}{c}\text { Tax } \\
\text { deductible for } \\
24000 \text { CZK } \\
\text { of the client's } \\
\text { payment } \\
\text { above } 12000 \\
\text { CZK per year. } \\
\text { Tax deductible } \\
\text { for employer } \\
\text { contribution } \\
\text { up to } \\
30 \text { 000 CZK } \\
\text { per year. }\end{array}$ & $\begin{array}{c}\text { Tax } \\
\text { deductible for } \\
24000 \text { CZK } \\
\text { of the client's } \\
\text { payment } \\
\text { above } 12000 \\
\text { CZK per year. } \\
\text { Tax deductible } \\
\text { for employer } \\
\text { contribution } \\
\text { up to } \\
30 \text { 000 CZK } \\
\text { per year. }\end{array}$ & $\begin{array}{c}\text { Capital return } \\
\text { tax abolished } \\
\text { after holding } \\
\text { the } \\
\text { investment } \\
\text { for more than } \\
6 \text { months } \\
\text { (tax test). }\end{array}$ & $\begin{array}{c}\text { Capital return } \\
\text { tax abolished } \\
\text { after holding } \\
\text { the } \\
\text { investment } \\
\text { for more than } \\
6 \text { months } \\
\text { (tax test). }\end{array}$ & $\begin{array}{c}\text { Tax } \\
\text { deductible for } \\
12000 \mathrm{CZK} \\
\text { of the client's } \\
\text { payment. } \\
\text { Tax } \\
\text { deductible } \\
\text { for employer } \\
\text { contribution } \\
\text { up to } \\
30 \text { 000 CZK } \\
\text { per year. }\end{array}$ \\
\hline Entrance fee & None & None & $\begin{array}{c}\text { Usually up to } \\
3 \%\end{array}$ & $\begin{array}{l}\text { Usually up to } \\
3 \%\end{array}$ & $\begin{array}{c}\text { Usually up to } \\
5 \%\end{array}$ \\
\hline $\begin{array}{l}\text { Management } \\
\text { fee }\end{array}$ & $\begin{array}{c}0.4 \% \text { p.a. } \\
\text { (capped by } \\
\text { law) }\end{array}$ & $\begin{array}{c}0.6 \% \text { p.a. } \\
\text { (capped by } \\
\text { law) }\end{array}$ & $\begin{array}{l}\text { Usually up to } \\
1.5 \% \text { p.a. }\end{array}$ & $\begin{array}{l}\text { Usually up to } \\
1.5 \% \text { p.a. }\end{array}$ & $\begin{array}{l}\text { Usually up to } \\
3 \% \text { p.a. }\end{array}$ \\
\hline $\begin{array}{l}\text { Performance } \\
\text { fee }\end{array}$ & $\begin{array}{c}10 \% \text { of annual } \\
\text { return } \\
\text { (capped by } \\
\text { law) }\end{array}$ & $\begin{array}{c}15 \% \text { of annual } \\
\text { return } \\
\text { (capped by } \\
\text { law) }\end{array}$ & Usually none & Usually none & Usually none \\
\hline
\end{tabular}




\begin{tabular}{|c|c|c|c|c|c|}
\hline & $\begin{array}{l}\text { Supple- } \\
\text { mentary } \\
\text { pension } \\
\text { savings } \\
\text { (SPS) }^{A}\end{array}$ & $\begin{array}{l}\text { Supple- } \\
\text { mentary } \\
\text { pension } \\
\text { insurance } \\
(\mathrm{SPI})^{\mathrm{A}}\end{array}$ & $\begin{array}{l}\text { Investment } \\
\text { fund } \\
\text { (IF) with } \\
\text { up-front } \\
\text { commission }{ }^{A}\end{array}$ & $\begin{array}{l}\text { Investment } \\
\text { fund } \\
\text { (IF) without } \\
\text { up-front } \\
\text { commission }\end{array}$ & $\begin{array}{l}\text { Unit-linked } \\
\text { life } \\
\text { insurance } \\
(U L I)^{A}\end{array}$ \\
\hline $\begin{array}{l}\text { Up-front } \\
\text { costs } \\
\text { (regular } \\
\text { payments) }\end{array}$ & $\begin{array}{c}\text { None } \\
\text { (banned by } \\
\text { the law) }\end{array}$ & $\begin{array}{c}\text { None } \\
\text { (banned by } \\
\text { the law) }\end{array}$ & $\begin{array}{c}\text { Up to } \\
\text { the equivalent } \\
\text { of } 100 \% \\
\text { of yearly } \\
\text { investment } \\
\text { (pre-paid } \\
\text { entrance fee } \\
\text { - incurred } \\
\text { gradually over } \\
1-5 \text { years). }\end{array}$ & None & $\begin{array}{c}\text { Always } \\
\text { present, up to } \\
\text { the equivalent } \\
\text { of two yearly } \\
\text { payments } \\
\text { (incurred fully } \\
\text { in the first } 2 \\
\text { years). }\end{array}$ \\
\hline $\begin{array}{l}\text { Total } \\
\text { expense } \\
\text { ratio (TER) }\end{array}$ & $\sim 0.5 \%$ p.a. & $\sim 0.9 \%$ p.a. & $\sim 2 \%$ & $\sim 2 \%$ & $\sim 4 \%$ \\
\hline $\begin{array}{l}\text { One-time } \\
\text { contributions }\end{array}$ & Possible & Possible & $\begin{array}{c}\text { Possible } \\
\text { (no up-front } \\
\text { costs) }\end{array}$ & $\begin{array}{c}\text { Possible } \\
\text { (no up-front } \\
\text { costs) }\end{array}$ & $\begin{array}{c}\text { Possible } \\
\text { (no up-front } \\
\text { costs) }\end{array}$ \\
\hline $\begin{array}{l}\text { Preliminary } \\
\text { surrender }\end{array}$ & $\begin{array}{l}\text { Possible } \\
\text { before } \\
\text { retirement } \\
\text { date, but state } \\
\text { subsidies } \\
\text { and tax } \\
\text { deductibles } \\
\text { have to be } \\
\text { repaid. }\end{array}$ & $\begin{array}{l}\text { Possible } \\
\text { before } \\
60 \text { years } \\
\text { of age, } \\
\text { but state } \\
\text { subsidies } \\
\text { and tax } \\
\text { deductibles } \\
\text { have to be } \\
\text { repaid. } \\
\text { Possible after } \\
60 \text { years } \\
\text { of age without } \\
\text { sanctions. }\end{array}$ & $\begin{array}{l}\text { Possible } \\
\text { without } \\
\text { sanctions. } \\
\text { Up-front costs } \\
\text { are incurred. }\end{array}$ & $\begin{array}{l}\text { Possible } \\
\text { without } \\
\text { sanctions. }\end{array}$ & $\begin{array}{l}\text { Possible } \\
\text { but tax } \\
\text { deductibles } \\
\text { have to be } \\
\text { repaid. } \\
\text { Up-front costs } \\
\text { are incurred. }\end{array}$ \\
\hline \multicolumn{6}{|c|}{$\begin{array}{l}\text { A Regularly (monthly) paid contributions and investments only are taken into account, unless } \\
\text { stated otherwise. As previously mentioned, we deal with the conservative strategy of the SPS } \\
\text { and SPI, compared with the conservative (bond) funds of IF and ULI respectively. } \\
\text { B Law No. } 427 / 2011 \text { on supplementary pension savings }\end{array}$} \\
\hline
\end{tabular}

Source: own research using (APS, 2018; Lhotská, 2014). 
Table 2 | Distribution features analysis (2013)

\begin{tabular}{|c|c|c|c|c|c|}
\hline & $\begin{array}{l}\text { Supple- } \\
\text { mentary } \\
\text { pension } \\
\text { savings } \\
\text { (SPS) }^{A}\end{array}$ & $\begin{array}{l}\text { Supple- } \\
\text { mentary } \\
\text { pension } \\
\text { insurance } \\
(\mathrm{SPI})^{\mathrm{A}}\end{array}$ & $\begin{array}{l}\text { Investment fund } \\
\text { (IF) with } \\
\text { up-front } \\
\text { commission }^{A}\end{array}$ & $\begin{array}{l}\text { Investment } \\
\text { fund } \\
\text { (IF) without } \\
\text { up-front } \\
\text { commission }\end{array}$ & $\begin{array}{l}\text { Unit-linked } \\
\text { life } \\
\text { insurance } \\
\text { (ULI) }^{A}\end{array}$ \\
\hline $\begin{array}{l}\text { Up-front } \\
\text { commission }\end{array}$ & $\begin{array}{l}880 \text { CZK } \\
\text { (flat capped } \\
\text { by law at } \\
1.5 \% \text { of the } \\
\text { average } \\
\text { salary) }\end{array}$ & $\begin{array}{l}4000 \mathrm{CZK}^{\mathrm{B}} \\
\text { (usually } \\
\text { equal to } \\
\text { about } 400 \% \\
\text { of the } \\
\text { monthly } \\
\text { payment) }\end{array}$ & $\begin{array}{l}11400 \mathrm{CZK}^{\mathrm{B}} \\
\text { (usually equal } \\
\text { to about } 95 \% \\
\text { of the yearly pay- } \\
\text { ment equivalent, if } \\
\text { up-front commis- } \\
\text { sion is enabled) }\end{array}$ & None & $\begin{array}{l}20000 \mathrm{CZK}^{\mathrm{B}} \\
\text { (usually } \\
\text { equal to as } \\
\text { much as } \\
180 \% \text { times } \\
\text { of the yearly } \\
\text { payment) }\end{array}$ \\
\hline $\begin{array}{l}\text { Trail } \\
\text { commission }\end{array}$ & None & None & $\begin{array}{l}\text { Usually around } \\
0.25 \% \text { p.a. }\end{array}$ & $\begin{array}{c}\text { Usually } \\
\text { around } 3.25 \% \\
\text { p.a. }\end{array}$ & $\begin{array}{c}\text { Usually } \\
\text { around } 1 \% \\
\text { p.a. }\end{array}$ \\
\hline $\begin{array}{l}\text { Other } \\
\text { inducements } \\
\text { and conflicts } \\
\text { of interest }\end{array}$ & $\begin{array}{c}\text { None } \\
\text { (banned by } \\
\text { law) }\end{array}$ & $\begin{array}{c}\text { Sparse, } \\
\text { unregulated }\end{array}$ & $\begin{array}{l}\text { Quality enhance- } \\
\text { ment criterion }\end{array}$ & $\begin{array}{c}\text { Quality } \\
\text { enhancement } \\
\text { criterion }\end{array}$ & $\begin{array}{l}\text { Common, } \\
\text { unregulated }\end{array}$ \\
\hline $\begin{array}{l}\text { Tied agent } \\
\text { registration } \\
\text { fee }\end{array}$ & $2000 \mathrm{CZK}$ & $1000 \mathrm{CZK}$ & $0 \mathrm{CZK}$ & $0 \mathrm{CZK}$ & $10000 \mathrm{CZK}$ \\
\hline $\begin{array}{l}\text { Tied agent } \\
\text { annual } \\
\text { renewal of } \\
\text { registration } \\
\text { fee }\end{array}$ & $1000 \mathrm{CZK}$ & $0 \mathrm{CZK}$ & $0 \mathrm{CZK}$ & $0 \mathrm{CZK}$ & $0 \mathrm{CZK}$ \\
\hline $\begin{array}{l}\text { Entrance } \\
\text { exams }\end{array}$ & $\begin{array}{l}\text { Obligatory } \\
\text { and strict }\end{array}$ & None & $\begin{array}{l}\text { Only in the } \\
\text { minority of cases } \\
\text { (insufficient } \\
\text { general education } \\
\text { or practice) }\end{array}$ & $\begin{array}{l}\text { Only in the } \\
\text { minority of } \\
\text { cases } \\
\text { (insufficient } \\
\text { general } \\
\text { education } \\
\text { or practice) }\end{array}$ & $\begin{array}{l}\text { Obligatory } \\
\text { but formal }\end{array}$ \\
\hline $\begin{array}{l}\text { Code } \\
\text { of conduct } \\
\text { and sales } \\
\text { management } \\
\text { system } \\
\text { requirement }\end{array}$ & $\begin{array}{l}\text { Full MiFID I } \\
\text { requirements }\end{array}$ & None & $\begin{array}{l}\text { Full MiFID I } \\
\text { requirements }\end{array}$ & $\begin{array}{l}\text { Full MiFID I } \\
\text { requirements }\end{array}$ & $\begin{array}{l}\text { Only } \mathrm{IMD}^{\mathrm{C}} \\
\text { requirements }\end{array}$ \\
\hline \multicolumn{6}{|c|}{$\begin{array}{l}{ }^{A} \text { Regularly (monthly) paid contributions and investments only are taken into account unless } \\
\text { stated otherwise. As previously mentioned, we deal with the conservative strategy of the SPS } \\
\text { and SPI, compared with the conservative (bond) funds of IF and ULI respectively. } \\
{ }^{\mathrm{B}} \text { Example calculated for } 1000 \text { CZK monthly paid contributions and contract length of } 30 \text { years. } \\
{ }^{C} \text { MiFID I = Markets in Financial Instruments Directive, IMD = Insurance Mediation Directive. }\end{array}$} \\
\hline
\end{tabular}

Source: own research using (APS, 2018). 
Regarding further development since January 2013, the regulatory regime of the surveyed products was amended several times. Supplementary pension savings were substantially reformed by January 2016 by doubling the commission cap and relaxing some of the regulatory requirements for agents (e.g. registration fee extended to 24 months). Employer tax deductibles were also increased to $50000 \mathrm{CZK} /$ year, beginning in January 2017. The investment funds tax test was lengthened from 6 months to 36 months as of 2014. Finally, unit-linked insurance rules for employer contributions were tightened in 2015 by disabling tax deductibles with preliminary surrenders. An obligatory five years commission clawback was introduced in December 2017 for life insurance policies and, finally, the level of tax support was increased in 2017 by setting the employer tax deductible at $50000 \mathrm{CZK} /$ year. All of these changes will be projected in the following sales development analysis.

\subsection{Sales and Population Penetration of the New Supplementary Pension Savings}

The previous chapter summarised the product and distribution features of the new supplementary pension savings and the alternatives. What was the ultimate outcome of this solution and the substitute products on the Czech market?

Figure 1 | Surveyed products sales overview (number of new contracts)

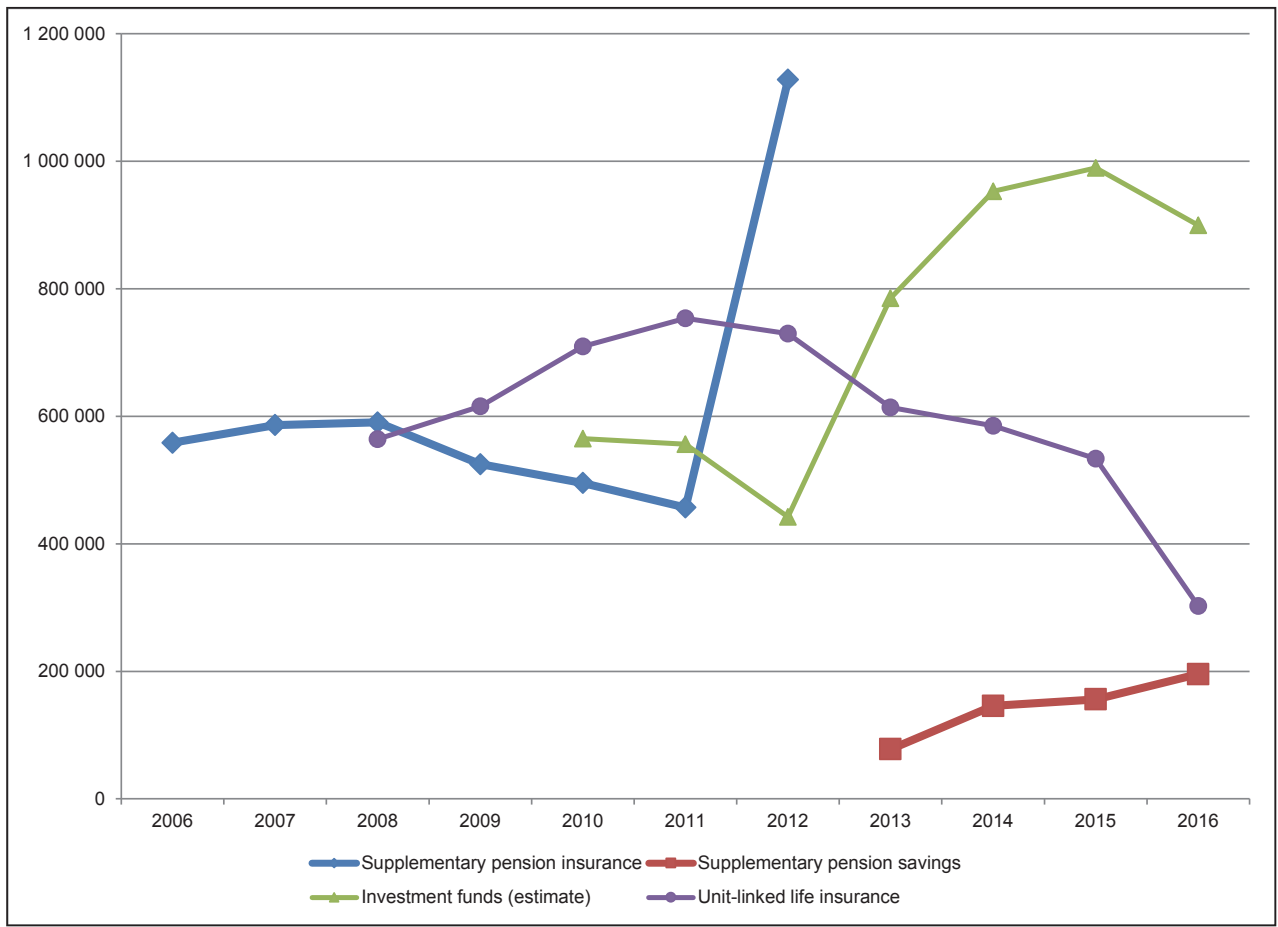

Source: own research using (MF, 2018; CNB, 2018). 
The timeline of the sales development indicates three important findings. First, while the 'old' supplementary pension insurance was able to acquire around half a million new participants a year, albeit with a decreasing trend, new supplementary pension savings were launched with a notable fall to less than 100,000 including conversions from the older system. The new third pillar never fully recovered from this slump, although there was a slight increase in annual sales, particularly after the easing of regulations in 2016. Alternative products dramatically out-sold new pension savings for the whole period of 2013-2016, with unit-linked insurance losing ground from 2011, yet still gaining more new contracts than pension savings. Investment funds were the most popular solution in terms of annual sales and out-sold pension savings by more than four times, although showing many almost identical product features. How did this development translate into the number of participants in the third pillar system?

Figure 2 | Third pillar system participation - total number of contracts

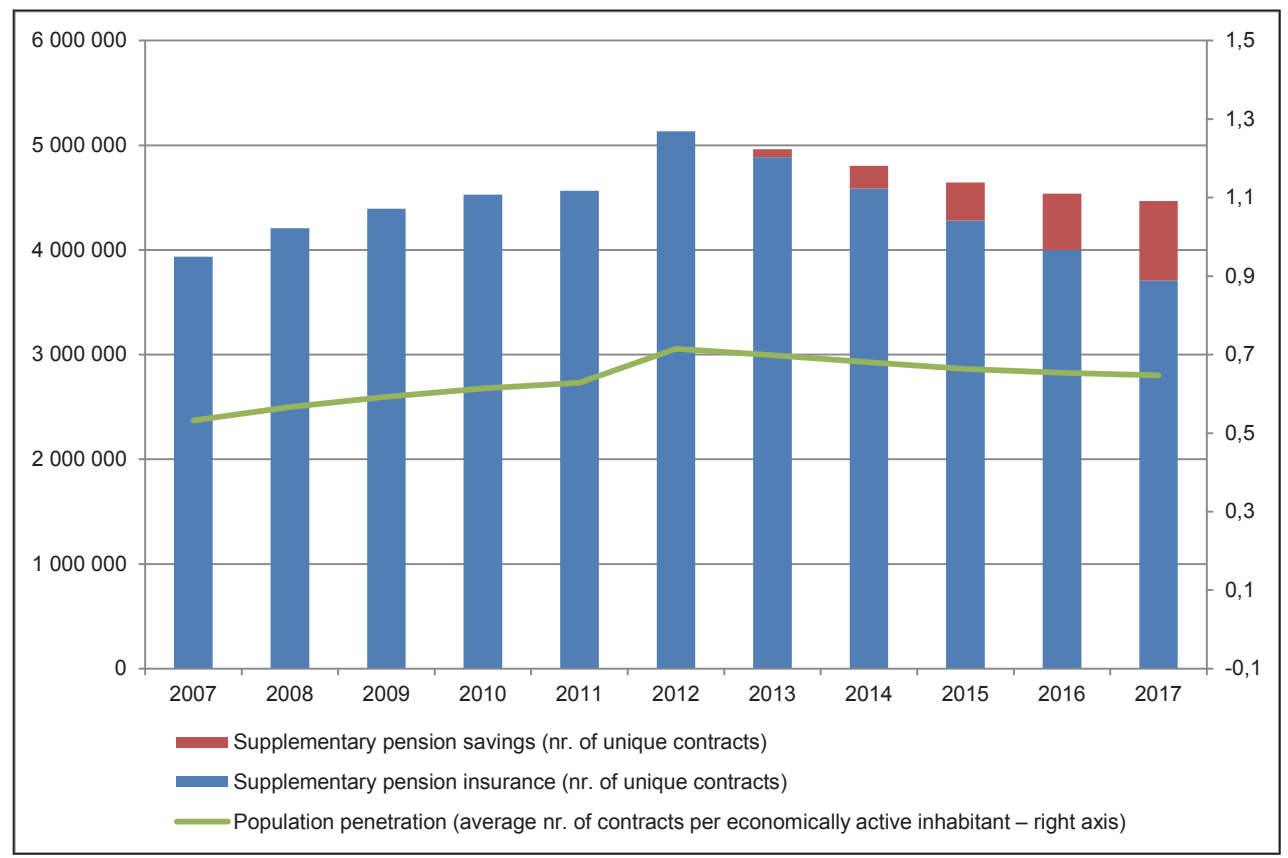

Source: own research using (CZSO, 2018; MF, 2018; CNB, 2018).

The number of participants in both third pillar systems underlines our earlier findings (one should bear in mind that the total number of participants is also affected by the finished contracts). While we have accepted the 2012 peak figures with caution (as the sales data indicates a speculative rally on an old system occurred), combined figures have been gradually decreasing since then. By 2017, the system had fewer participants than the old pension insurance had in 2011, which is indeed a worrisome development. The same development can be observed with the population penetration (economically active inhabitants), which after the 2012 spike declined close to the 2007 value. The new system conversion of the client base is also rather slow, with almost 
four-fifths of the participants remaining in the old pension insurance system, despite its relative weaknesses such as a lack of other investment strategies or slightly higher fees.

All in all, the empirical data on the supplementary pension savings indicate that its market performance to date was dubious at best. The hypothesis that a new product based purely on an investment vehicle with a heavy layer of regulation and state support would out-sell the old pension insurance and other substitutes was not successful. Clearly, the new product did not live up to the expectations set by the government as documented earlier. The source of the sales slump, the main source of the gradual 'dying up'of the participants' base, was at the same time, clear. Independent sales agents, responsible for a dominant share of the new business, showed a dramatic decrease of almost 93\% in 2013, compared to the 2011 annual sales of the former pension insurance. Subsequent recovery was very limited and slow.

\section{Discussion}

From a product features perspective, supplementary pension savings had every advantage to be a great customer success. With competitors more costly and much less supported by state subsidies and an old system vastly obsolete and unable to produce returns over inflation (Vocílka, 2017), what could have gone wrong? Arguably, the new product (Supplementary Pension Savings) was over-regulated and the distribution strategy projected in law by the government did not work. While the reform heavily relied on simple online sales of attractive, standardised solutions, this is a very controversial approach to a product that is typically and intensely reliant on active sales at least in the Central-European context, as suggested by Börsch-Supan et al. (2007). As the overall charges were also pushed down, pension funds had few options to compensate for the regulatory inhibition of agent-based sales channels. The attractiveness of the new supplementary pension savings to distributors was clearly undercut; not only was the commission cap set far below rewards with competitive products, but the code-of-conduct rules also made the situation even worse. Consequently, the gravitation of agents, a dominant sales channel up to that time, to other long-term investment solutions was predictable (Anagol et al., 2017; Linainmaa et al., 2017). Without proper advice, most clients ended up in a conservative strategy - a highly suboptimal strategy for long-term investments. Reviewing this negative experience, calls for further regulation, caps and limits to competition (such as shown by Casey and Whiteside, 2014 or Vostatek, 2012; 2015) would clearly lead up a blind alley. The industry would end up with a theoretically perfect product but with few customers taking part.

There is, however, another element that could possibly come into play and that is government (political) support. While the Ministry of Finance did launch an advertisement campaign, ${ }^{7}$ most authors agree that the political disputations over the new system had a dominantly negative effect on potential new participants (Jetmar, 2014). Yet this was mostly true with the second pillar, the retirement savings, which was also targeted by government promotion. While the spillover from the political uncertainty on the supplementary pension savings cannot be excluded, there was no open hostility from

7 According to open sources, the campaign investment was worth 20 million CZK, lasted approximately six months and focused solely on the new second pillar. 
the opposition to changes in the third pillar. Moreover, the next government, formed by the former opposition parties, made notable steps to further improve the system in 2017, indicating its supportive position. These product alternations, the increase in the tax benefit as well as less strict preliminary surrender options, and the possibility to open contracts for under-age participants, might have been a major factor in the gradual market recovery from 2013 onwards. However, these changes were also accompanied by reliefs in the distribution regime (moratorium on renewal fees, doubling of the commission cap), so the effect is probably combined.

When estimating the 'equilibrium' level of SPS and SPI sales, it is reasonable to assume that by 2006-2008 the market was saturated and the new sales contracts should mainly perform a reproductive function of the consumer basis. That should mainly affect the age structure of participants, which exhibits gradual degradation: while in 2009, the ratio of 25-30 years and 65+ years cohort was $21.1 \% / 15.9 \%$, in 2016 the numbers were much less favourable: 7.59\% / 15.58\% (MF, 2018 - SPI data). Worsening age structure could definitely be one of the factors that stimulated the 'dying-up' development of the decreasing population penetration as shown earlier. With supplementary pension savings, the situation is even worse.

Would the third pillar reform fare differently almost five years later, with the general push for the online, disruptive distributors? This is perhaps the most important question in relation to the new PEPP proposal. In the authors' opinion, similar results as in 2013 could be expected. There is very little supportive evidence of significant change in distribution models related to long-term savings products that need to be 'sold', rather than 'bought'. In reality, available evidence from Central Europe shows more limitations to online distribution (Braun et al., 2016). Arguably, this trend would be even stronger in countries with lower financial literacy, such as Central-Eastern Europe. To this end, however, similar results were observed in some segments after the commission ban following the UK Retail distribution directive (RDR) endeavour as well (Towers Watson, 2014). All in all, this is the most important lesson for PEPP and other similar reforms; previous mistakes should not be repeated.

\section{Conclusions}

The aim of this paper was to analyse the Czech third pillar reform experience. We conducted a comparative analysis of the new pension solution with the main alternatives, as well as discussed the subsequent sales performance and market penetration. Our results support three main conclusions:

(i) While heavy standardisation of the product appears to be an advantage on paper, a lack of investment options is, in reality, viewed more as a weakness. Positive effects in facilitating online sales are, on the other hand, dubious. Consumer uncertainty reduction remains, in comparison with similarly transparent products (such as UCITS investment funds) ${ }^{8}$, questionable.

8 Standard funds regulated by the Undertakings for the Collective Investment of Transferable Securities (UCITS) European directive. 
(ii) Relying on online distribution while inhibiting the offline channels with severe regulation measures is a highly questionable strategy with pension products. Moreover so, if the public sector is planning to compensate for the regulated channel using its own devices such as a promotional campaign, where the results in the Czech Republic were feeble.

(iii) Finally, even an attractive product design is not able to outweigh inhibited distribution with a product solution reliant on active sales and exposed to commercial competitors operating under a considerably lower regulation grip. Arguably with the Czech case, success was not achieved despite generous direct (subsidies) and indirect (tax) contributions.

Our findings are limited by the market data available and the five-year time period passed since the launch of the reform. To fully confirm the results presented, longitudinal research needs to be conducted in order to reflect long-term trends in the population and market behaviour. This would also be our primary aim in the future.

\section{References}

Anagol, S., Cole, S. and Sarkar, S. (2017). Understanding the Advice of Commissions-Motivated Agents: Evidence from the Indian Life Insurance Market. Review of Economics and Statistics, 99(1), pp. 1-15, https://doi.org/10.1162/REST_a_00625

Andel, R. (2014). Aging in the Czech Republic. The Gerontologist, 54(6), pp. 893-900, https://doi. org/10.1093/geront/gnu047

APS (Association of Pension Funds of the Czech Republic), (2018). Quarterly Pension Funds Results. [online] apfcr.cz. Available at: http://www.apfcr.cz/ctvrtletni-vysledky [Accessed 12 Mar. 2018]

Batty, I. and Hailichova, H. (2012). Major Pension Fund Reform in the Czech Republic: Creating a Three-pillar System. Pensions: An International Journal, 17(4), pp. 225-228, https://doi.org/10.1057/pm.2012.25

Börsch-Supan, A., Reil-Held, A. and Schunk, D. (2007). The Savings Behaviour of German Households: First Experiences with State Promoted Private Pensions [MEA Discussion Papers, 136-07]. Mannheim, Germany: Mannheim Research Institute for the Economics and Aging.

Braun, A., Schmeiser, H. and Schreiber, F. (2016). On Consumer Preferences and the Willingness to Pay for Term Life Insurance. European Journal of Operational Research, 253(3), pp. 761-776, https://doi.org/10.1016/j.ejor.2016.02.023

Casey, B. and Whiteside, N. (2014). Untangling the Pensions Web We've Woven. [online] warwick.ac.uk. Available at: https://warwick.ac.uk/fac/soc/sociology/staff/whitesiden/ whitesiden_index/recent_publications/casey_whiteside_may2011.pdf [Accessed 3 Apr. 2018]

CNB (Czech National Bank), (2018). The Database of ARAD Time Series. [online] cnb.cz. Available at: https://www.cnb.cz/docs/ARADY/HTML/index_en.htm [Accessed 12 Apr. 2018]

CZSO (Czech Statistical Office), (2018). Wages and Population - Time Series. [online] czso.cz. Available at: https://www.czso.cz/csu/czso/pmz_ts [Accessed 12 Jul. 2018] 
EU (European Commission), (2017). Proposal for a Regulation on a Pan-European Personal Pension Product (PEPP) [Consultation Proposal]. Brussels, Belgium: European Commission policies, information and services.

PES (Expert Advisory Forum), (2010). The Expert Advisory Forum's Final Report [Working Paper]. Prague, Czech Republic: Ministry of Finance.

Janíčko, M., and Tsharakyan, A. (2013). Sustainability of Pay-As-You-Go Pension System in Context of Population Aging in the Czech Republic. Politická ekonomie, 61(3), pp. 321-327, https://doi.org/10.18267/j.polek.900

Jetmar, J. (2014). Determinants of Czech Citizens' Entry into the Pension Second Pillar. [online] vse.cz. Available at: https://insis.vse.cz/zp/portal_zp.pl?podrobnosti_zp=46796 [Accessed 3 Apr. 2018]

Krebs, V. (2012). The Best Pension Reform Is the Pro-population Policy. [online] vsfs.cz. Available at: http://www.vsfs.cz/prilohy/konference/krebs_duchodova_reforma_2012.pdf [Accessed 3 Apr. 2018]

Lhotská, K. (2014). Analysis of Czech Pension System Costs [Working Paper]. Prague, Czech Republic: Ernst \& Young.

Linnainmaa, J. T., Melzer, B. T., Previtero, A. and Grace, C. (2015). Costly Financial Advice: Conflicts of Interest or Misguided Beliefs? [Working Paper]. London, Canada: Western University.

Loužek, M. (2014). Pension Reform. Prague: Karolinum Press.

MFCZ (Ministry of Finance, Czech Republic), (2018). Private Pension Systems. [online] mfcr.cz. Available at: http://www.mfcr.cz/cs/soukromy-sektor/soukrome-penzijni-systemy/iii-pilirdoplnkove-penzijni-sporeni-a-p [Accessed 3 Apr. 2018]

Schneider, O. (2011). Pension Systems in Europe: Everybody Reforms [Working Paper 6/2011]. Prague, Czech Republic: Institut pro demokracii a ekonomickou analýzu (IDEA).

Towers Watson, (2014). Advice Gap Analysis: Report to FCA [Towers Watson Research Paper No. 5/2014]. London, UK: Financial Conduct Authority.

USF (Union of Financial Intermediaries and Advisers), (2018). Market of Financial Intermediation and Advice. [online] usfcr.cz. Available at: http://www.usfcr.cz/financne-poradensky-trh/ [Accessed 12 Mar. 2018]

Vocílka, A. (2017). Respectable Pension with Third-pillar funds? FOND SHOP, 6, pp. 12-14.

Vostatek, J. (2012). Pension Reform: What Next? [online] vsfs.cz. Available at: http://www.vsfs.cz/prilohy/konference/vostatek_duchodova_reforma_2012.pdf. [Accessed 3 Apr. 2018]

Vostatek, J. (2015). Social and Sales Models of Pension Savings and Insurance. ACTA VŠFS, 9, pp. 74-103. 